

\title{
Geotechnical Stabilization of Clayey Soils by use of Rice Husk Ash and Alccofine 1101
}

\author{
Shafayat Ahmad Rather ${ }^{1}$, Neeraj Sharma ${ }^{2}$, Irfan Ahmad Najar ${ }^{3}$ \\ ${ }^{1}$ PG Student, Civil Engineering Department, SSCET Badhani (Pathankot) \\ ${ }^{2}$ Assistant professor, Civil Engineering Department, SSCET Badhani (Pathankot) \\ ${ }^{3} \mathrm{PhD}$ scholar, NIT Srinagar.
}

\begin{abstract}
The potential of using rice husk ash (RHA) and alccofine 1101 in stabilization of clayey soil is evaluated in this study. The combined use of these two materials to form a binder provides new opportunities to enhance engineering characteristics of expansive clays. The results revealed that maximum decrease in the liquid limit (40.20\%) was observed at $10 \%$ rice husk ash and $5 \%$ alccofine. The plastic limit of the clayey soil has been improved by $24.31 \%$ to $34.90 \%$ on addition of rice husk ash from $0 \%$ to $10 \%$ and alccofine from 0 to 5\%. The plasticity index of the clayey soil has been decreased by $26.09 \%$ to $5.30 \%$ on addition of rice husk ash from $0 \%$ to $10 \%$ and alccofine from 0 to $5 \%$. It is found that the MDD decreased from $1.49 \mathrm{~g} / \mathrm{cm} 3 \mathrm{to} 1.29 \mathrm{~g} / \mathrm{cm} 3$ of the clayey soil on addition of rice husk ash from $0 \%$ to $10 \%$ and alccofine from 0 to $5 \%$. However, increasing the concentration of alccofine 1101 in mixes increased the MDD values than mixes with $\mathrm{RHA}$ alone. The results concluded that increasing percentages of rice husk ash and alccofine added for stabilization of clayey soil enhances its strength.
\end{abstract}

Keywords: Clayey soil, rice husk ash, alccofine 1101, engineering characteristics

\section{INTRODUCTION}

Clayey soils are microscopic and sub-microscopic particles that change significantly in volume with changes in water content. Clayey soil often possesses poor strength characteristic and pose serious construction problem causing large differential settlement to the structure constructed over them (Kanddulna et al., 2016). Since clayey soil exhibit high swelling and shrinkage when exposed to change in moisture content and hence found to be most troublesome from engineering considerations. This behaviour is due to presence of a mineral montmorillonit, kaolinite and illite but mostly due to montmorillonit. Soil improvement could either be by modification or stabilization or both. The stabilization of clayey soil in such location is required by using various admixtures so that the strength of subgrade characteristic of soil can be improved. Soil modification is the addition of a modifier (cement, lime, ash, etc.) to a soil to change its index properties, while soil stabilization is the treatment of soils to enable their strength and durability to be improved such that they become totally suitable for construction beyond their original classification (Kumar and Preethi, 2014). Mixing stabilizers in a particular amount in clay soils induce textural change and give better improved strength. Rice husk is an agricultural waste obtained from milling of rice. Rice milling generates a huge by product of rice husk. During milling of paddy about $78 \%$ of weight is, received as rice, broken rice and bran. Rest $22 \%$ of the weight of paddy is received as husk. So, for every $1000 \mathrm{~kg}$ of paddy milled, about $220 \mathrm{~kg}(22 \%)$ of husk is produced, and when this husk is burnt in the boilers, about $55 \mathrm{~kg}(25 \%)$ of RHA is generated. India is a major rice producing country, and the husk generated during milling is mostly used as a fuel in the boilers for processing paddy, producing energy through direct combustion and/ or by gasification. An about 20 million tons of RHA is produced annually (Rao et al., 2012). About 108 tonnes of rice husk is generated annually in the world. Rice husk ash has so much been utilized in the past for upgrading of soils (Okafor and Okonkwo, 2009). In Nigeria, about 2.0 million tons of rice is produced annually. Meanwhile, the ash has been categorized under pozzolana, with about $67-70 \%$ silica and about $4.9 \%$ and $0.95 \%$, Alumina and iron oxides, respectively (Oyetola and Abdullahi, 2006). In most cases the RHA was used as an admixture and a stabilizing agent (cement or lime) included to increase the cementitious property of the stabilized matrix. It has been shown that both cement and RHA reduced the plasticity of soils and MDD but increased OMC (Basha et al., 2005). Alccofine is a new generation, micro fine material of particle size much finer than other hydraulic materials like cement, fly ash, silica etc. being manufactured in India. Alccofine has unique characteristics to enhance performance of concrete in fresh and hardened stages due to its optimized particle size distribution. There are two types of alccofine i.e., alccofine 1203 and alccofine 1101 (Shadi and Banarase, 2015). Alccofine is an alccofine with low calcium silicate. Alccofinee 1200 series is of 1201, 1202, 1203 which represents fine, micro fine, ultrafine particle size respectively. Alccofine 1101 is an alccofine with high calcium silicate. It is a micro finer cementitious grouting material for soil stabilization and rock anchoring. The performance of Alccofine is superior to all other 
admixtures used in India. Due to high calcium oxide $(\mathrm{CaO})$ content performance of concrete in fresh and hardened stages due to its optimized particle size distribution. Therefore, the objective of the study was to optimize the levels of rice husk ash and alccofine in clayey soil based on consistency limit tests and the maximum dry density.

\section{A. Materials and methods Materials}

1) Soil: Locally available clay obtained from Kathua, Jammu and Kashmir is used for the study.

2) Rice husk ash (GSA): Rice husk ash, procured from Ludhiana was used for the study. Rice husk were incinerated at $600{ }^{\circ} \mathrm{C}$ resulting in rice husk ash.

3) Alccofine 1101: Alccofine 1101 was used for the study obtained from commercial supplier.

\section{METHODOLOGY}

Table 1: Formulation of mixes containing clay, rice husk ash and alccofine 1101

\begin{tabular}{|c|c|c|c|}
\hline $\begin{array}{l}\text { S. } \\
\text { No. }\end{array}$ & $\begin{array}{l}\text { Clay } \\
(\%)\end{array}$ & $\begin{array}{l}\text { Rise Husk } \\
\text { Ash }(\%)\end{array}$ & $\begin{array}{l}\text { Alccofine } \\
1101(\%)\end{array}$ \\
\hline 1 & 100 & 0 & 0 \\
\hline 2 & 95 & 5 & 0 \\
\hline 3 & 92.5 & 7.5 & 0 \\
\hline 4 & 90 & 10 & 0 \\
\hline 5 & 99 & 0 & 1 \\
\hline 6 & 94 & 5 & 1 \\
\hline 7 & 91.5 & 7.5 & 1 \\
\hline 8 & 89 & 10 & 1 \\
\hline 9 & 97 & 0 & 3 \\
\hline 10 & 92 & 5 & 3 \\
\hline 11 & 89.5 & 7.5 & 3 \\
\hline 12 & 87 & 10 & 3 \\
\hline 13 & 95 & 0 & 5 \\
\hline 14 & 90 & 5 & 5 \\
\hline 15 & 87.5 & 7.5 & 5 \\
\hline 16 & 85 & 10 & 5 \\
\hline
\end{tabular}

Percentage of clayey soil used in different mixed (100, 95, 92.5, 90, 95, 94, 91.5, 89, 97, 92, 89.5, 87, 95, 90, 87.5 and 85\%).

Percentage of alccofine as ratio to clayey soil used in different mixes (1, 3 and 5\%). Four mixes [Mix (1), Mix (2), Mix (3) and Mix (4)] with three different types of $0 \%$ of alccofine were used in this study as single additive are follows:

To study the effect of addition of rice husk ash in clayey soil mixed with alccofine-1101, the variables shown in Table 1 are considered in this study:

a) Mix. (1): clayey soil:RHA: Alccofine-1101- 100:0:0 (\%age By weight)

b) Mix. (2): clayey soil:RHA: Alccofine-110195:5:0 (\%age By weight)

c) Mix. (3): clayey soil:RHA: Alccofine-110192.5:7.5:0 (\%age By weight)

d) Mix. (4): clayey soil:RHA: Alccofine-1101-

90:10:0 (\%age By weight)

Three mixes [Mix (5), Mix (9), Mix (3) and Mix 
(13)] with $0 \%$ of RHA were used in this study as single additive are follows:

a) Mix. (5): clayey soil:RHA: Alccofine-1101- 99\%:0:1 (\%age By weight)

b) Mix. (9): clayey soil:RHA: Alccofine-110197:0:3 (\%age By weight)

c) Mix. (13): clayey soil:RHA: Alccofine-1101-

95:0:5 (\%age By weight)

The other mixes prepared for double additive are indicated below:

a) Mix. (6): clayey soil:RHA: Alccofine-1101- 95:5:1 (\%age By weight)

b) Mix. (7): clayey soil:RHA: Alccofine-110191.5:7.5:1 (\%age By weight)

c) Mix. (8): clayey soil:RHA: Alccofine-110189:10:1 (\%age By weight)

d) Mix. (10): clayey soil:RHA: Alccofine-110192:5:3 (\%age By weight)

e) Mix. (11): clayey soil:RHA: Alccofine-1101- 89:7.5:3 (\%age By weight)

f) Mix. (12): clayey soil:RHA: Alccofine-110187:10:3 (\%age By weight)

g) Mix. (14): clayey soil:RHA: Alccofine-110190:5:5 (\%age By weight)

h) Mix. (15): clayey soil:RHA: Alccofine-110187.5:7.5:5 (\%age By weight)

i) Mix. (16): clayey soil:RHA: Alccofine-1101-

85:10:5 (\%age By weight) Atterberg Limit:

The engineering behaviour of clayey soils is greatly influenced by changes in water content. The liquid limit and plastic limits represents the water contents of a soil when the soil ceases to behave like a liquid and a plastic solid, respectively. These limits are helpful in classifying clayey soils. The group to which the soil belongs to IS system of soil classification (IS: 1498-1970) can be determined with the help of liquid and plastic limits. It is important to carry out several simple tests to describe the plasticity of clay to avoid shrinkage and cracking when fired. Atterberg limit described an amount of water contents at certain limiting or critical stages in soil behaviour. If we know where the water content of our sample is relative to the atterberg limits, then we already know a great deal about the engineering response of our sample. This test is carried out in order to determine the stiffness of clay and parameters measured are plastic limit (PL) and liquid limit (LL). The behaviour of soil in term of plasticity index (PI) is determined by using the formula: PI = LL - PL.

\section{B. Plastic Limit}

Plastic limit represents the moisture content at which soil changes from plastic to brittle state. It is the upper strength limit of consistency. The simple method to do this test is by rolling a thread of soil (on a glass plate) until it crumbles at a diameter of 3 mm. Sample will reflect as wet side of the plastic limit if the thread can be rolled in diameter of below 3 mm and the dry side if the thread breaks up and crumbles before it reaches $3 \mathrm{~mm}$ diameter. The following procedure is adopted to find the plastic limit of the soil.

1) Take about $30 \mathrm{~g}$ of dried soil sample passing through 425 micron sieve.

2) Mix thoroughly with distilled water on the glass plate until it is plastic enough to be shaped into a small ball.

3) Take about $10 \mathrm{~g}$ of the plastic soil mass and roll it between the hand and the glass plate to form the soil mass into a thread of as small diameter as possible. If the diameter of the thread becomes less than $3 \mathrm{~mm}$ without cracks, it indicates that the water added to the soil is more than its plastic limit; hence the soil is kneaded further and rolled into thread again.

\section{Liquid Limit}

Liquid limit is expressed in terms of water content as a percentage. Liquid limit is the water content expressed in percentage at which the soil passes from zero strength to an infinitesimal strength, hence the true value of liquid limit cannot be determined. For determination purpose liquid limit is that water content at which a part of soil, cut by a groove of standard dimensions, will flow together for a distance of $12.5 \mathrm{~mm}$ under an impact of 5 blows in a standard liquid limit apparatus with a height of fall of $1 \mathrm{~cm}$.The moisture content expressed in percentage at which the soil has the smallest plasticity is called plastic limit. For determination purposes the plastic limit is defined as the water content at which a soil just begins to crumble when rolled into a thread of $3 \mathrm{~mm}$ in diameter. It is essentially a measure of a constant value of a lower strength limit of viscous shearing resistance as the soil approaches the liquid state. The following procedure is adopted to find the liquid limit of the soil.

1) Adjust the cup of liquid limit apparatus with the help of grooving tool gauge and the adjustment plate to give a drop of exactly $1 \mathrm{~cm}$ on the point of contact on the base.

2) Take about $120 \mathrm{gm}$ of an air-dried soil sample passing 425 -micron sieve.

3) Mix the soil thoroughly with some distilled water to form a uniform paste. 
4) Place a portion of the paste in the cup of the liquid limit device, smooth the surface with spatula to a maximum depth of $1 \mathrm{~cm}$. draw the grooving tool through the sample along the symmetrical axis of the cup, holding the tool perpendicular to the cup.

5) Turn the handle at a rate of 2 revolutions per second and count the blows until the two parts of the soil sample come in contact with each other, at the bottom of the groove along a distance of $10 \mathrm{~mm}$.

6) Transfer about $15 \mathrm{gm}$ of the soil sample forming the wedge of the groove that flowed together to a water content bin and determine the water content by oven drying.

7) Transfer the remaining soil in the cup to the main soil sample in the bowl and mix thoroughly after adding a small amount of water.

8) Repeat steps 4-7. Obtain at least five set of readings in the range of 10-40 blows.

\section{Proctor Compaction}

Compaction test were conducted to get the MDD of the mixes to study the effect of addition of rice husk ash in clayey soil mixed with alccofine-1101 using standard proctor compaction machine.

\section{E. Statistical Analysis}

All results were means of three replicates. Standard deviation was also taken of the three replicates in each test.

\section{RESULTS AND DISCUSSION ATTERBERG'S LIMIT}

The results of clayey soil mixed with rice husk ash and alccofine are shown in Figure 1 and Table 2. The liquid limit decreased from 53.40 to $40.20 \%$ with the addition of rice husk ash and alccofine-1101. The maximum decrease was observed at 10\% RHA and 5\% alccofine and can be considered to be as a result of the replacement of the soil fines by RHA stabilized by alccofine.

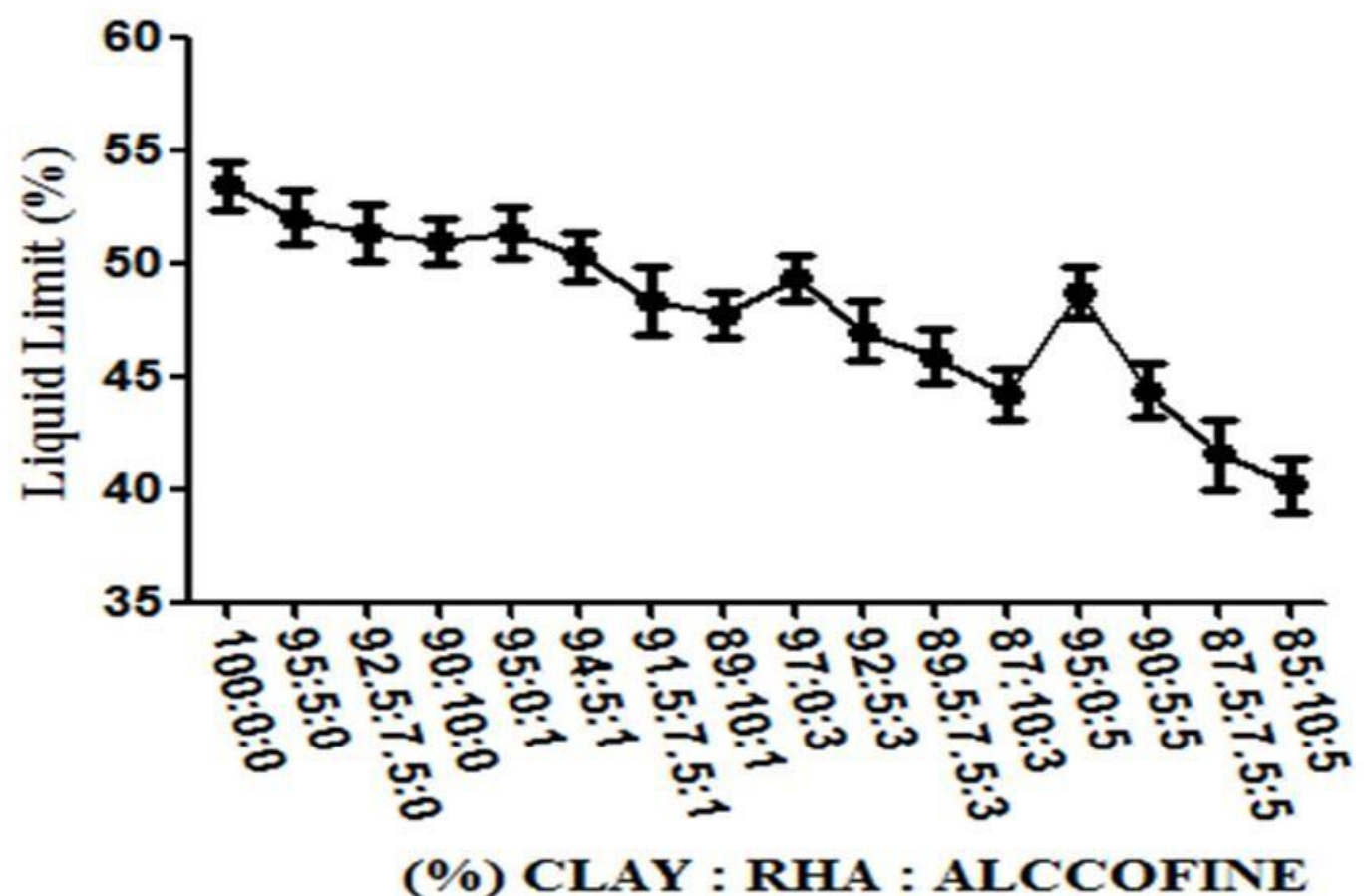

Figure 1: Variation of Liquid Limit (\%) with Rice Husk Ash and Alccofine Content

The results of plastic limit are shown in Figure 2 and value was observed at 10\% RHA and 5\% alccofine. Table 2. The results observed that Plastic limit Thus, with the increase in content of RHA and increased from 24.31 to $34.90 \%$ with the addition of alccofine the plastic limit of all samples increased. rice husk ash and alccofine-1101. The maximum 


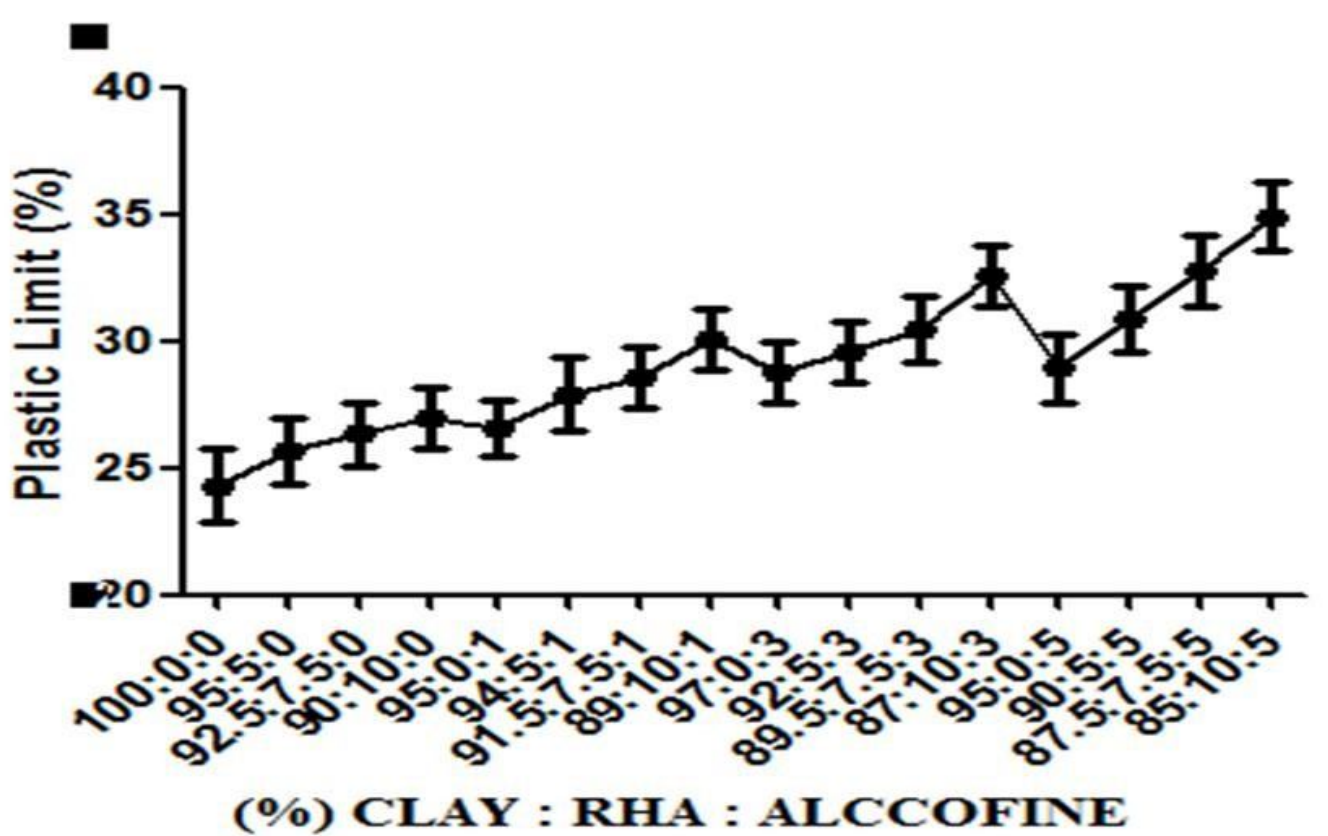

Figure 2: Variation of Plastic Limit (\%) with Rice Husk Ash and Alccofine Content

The results of plasticity Index are shown in Figure 3 and Table 2 . The plasticity index decreased from $26.09 \%$ to $5.30 \%$ with increase in RHA content and alccofine from $0 \%$ to 10.0 and $5.0 \%$. The maximum decrease was observed at 10\% RHA and $5 \%$ alccofine. This trend may be attributed to the replacement of the finer soil particles by the RHA and stabilization by alccofine with consequent reduction in the clay content and plasticity index. It was also observed that plasticity index of a soil increased as the amount clay fraction increased and vice versa (Arora, 2008).

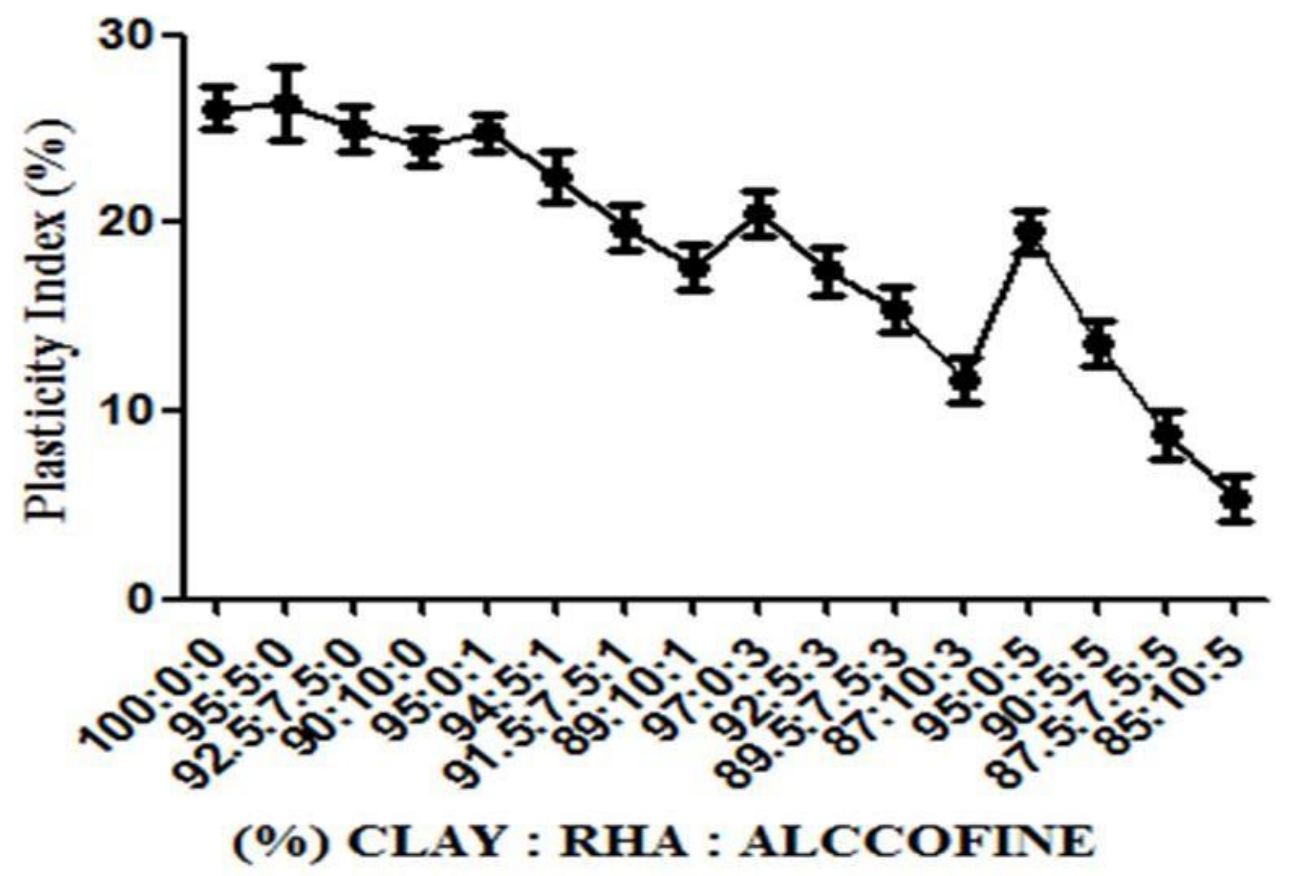

Figure 3: Variation of Plasticity Index (\%) with Rice Husk Ash and Alccofine Content 
International Journal for Research in Applied Science \& Engineering Technology (IJRASET) ISSN: 2321-9653; IC Value: 45.98; SJ Impact Factor: 6.887 Volume 7 Issue IV, Apr 2019- Available at www.ijraset.com

Table 2: Effect of RHA and Alccofine on LL, PL and PI of clayey soil

\begin{tabular}{|l|l|l|l|}
\hline Clay:RHA:Alccofine $(\%)$ & Liquid Limit $(\%)$ & Plastic Limit (\%) & $\begin{array}{c}\text { Plasticity Index } \\
(\%)\end{array}$ \\
\hline $100: 0: 0$ & 53.40 & 24.31 & 29.09 \\
\hline $95: 5: 0$ & 52.01 & 25.67 & 26.34 \\
\hline $92.5: 7.5: 0$ & 51.34 & 26.33 & 25.01 \\
\hline $90: 10: 0$ & 51.02 & 26.97 & 24.05 \\
\hline $95: 0: 1$ & 51.34 & 26.56 & 24.78 \\
\hline $94: 5: 1$ & 50.29 & 27.89 & 22.4 \\
\hline $91.5: 7.5: 1$ & 48.33 & 28.57 & 19.76 \\
\hline $89: 10: 1$ & 47.67 & 30.04 & 17.63 \\
\hline $97: 0: 3$ & 49.28 & 28.78 & 20.50 \\
\hline $92: 5: 3$ & 47.02 & 29.59 & 17.43 \\
\hline $89.5: 7.5: 3$ & 45.89 & 30.46 & 15.43 \\
\hline $87: 10: 3$ & 44.21 & 32.54 & 11.67 \\
\hline $95: 0: 5$ & 48.74 & 28.92 & 19.82 \\
\hline $90: 5: 5$ & 44.39 & 30.86 & 13.53 \\
\hline $87.5: 7.5: 5$ & 41.58 & 32.79 & 5.79 \\
\hline $85: 10: 5$ & 40.20 & 34.90 & 5.30 \\
\hline & & & \\
\hline
\end{tabular}

\section{A. Compaction Test}

Figure 4 shows the variation of MDD $(\mathrm{g} / \mathrm{cm} 3)$ with rice husk ash and alccofine content. The results indicated that between $0 \%$ and $10 \%$ RHA contents, the MDD decreased from $1.49 \mathrm{~g} / \mathrm{cm} 3$ to $1.29 \mathrm{~g} / \mathrm{cm} 3$ respectively. The decrease may be attributed to the replacement of clayey soil by RHA in the mixture which has relatively lower specific gravity of 2.25 compared to that of the clayey soil which is 2.50 . It may also be due to the coating of the clayey soil by the RHA which results to large particles with larger voids and hence less density (Jawad et al., 2014). However, with the increase in content of alccofine from $0 \%$ to 5\%, the MDD of mixes increases as compared to mixes containing only RHA.

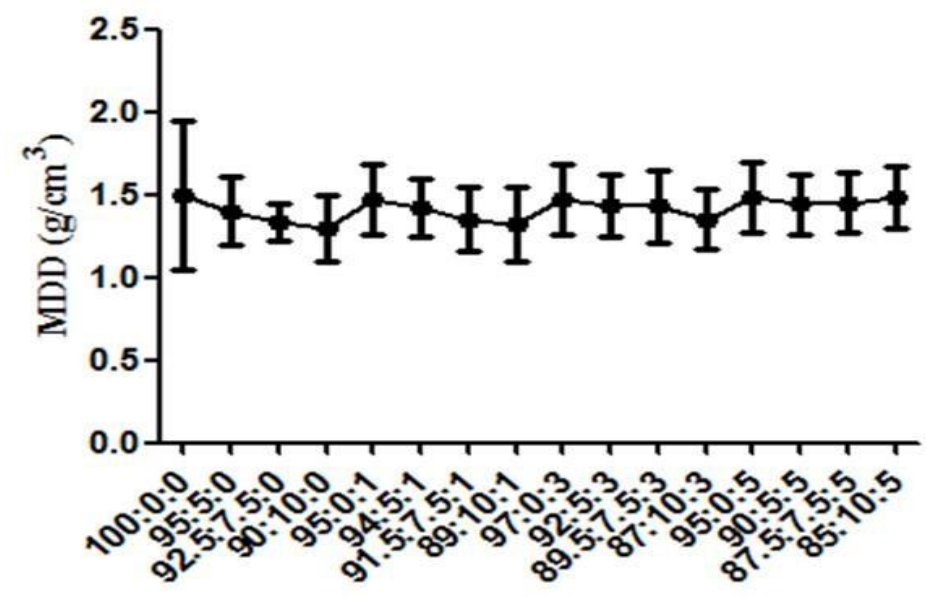

Figure 4: Variation of MDD $\left(\mathrm{g} / \mathrm{cm}^{3}\right)$ with Rice Husk Ash and Alccofine Content 


\section{International Journal for Research in Applied Science \& Engineering Technology (IJRASET)}

ISSN: 2321-9653; IC Value: 45.98; SJ Impact Factor: 6.887 Volume 7 Issue IV, Apr 2019- Available at www.ijraset.com

\section{IV.CONCLUSION}

It is noticed that the liquid limit of the clayey soil has been decreased by $53.40 \%$ to $40.20 \%$ on addition of rice husk ash from $0 \%$ to $10 \%$ and alccofine from 0 to $5 \%$. It is observed that the plastic limit of the clayey soil has been improved by $24.31 \%$ to $34.90 \%$ on addition of rice husk ash from $0 \%$ to $10 \%$ and alccofine from 0 to $5 \%$. It is observed that the plasticity index of the clayey soil has been decreased by $26.09 \%$ to $5.30 \%$ on addition of rice husk ash from $0 \%$ to $10 \%$ and alccofine from 0 to $5 \%$. It is found that the MDD decreased from $1.49 \mathrm{~g} / \mathrm{cm} 3$ to $1.29 \mathrm{~g} / \mathrm{cm} 3$ of the clayey soil on addition of rice husk ash from $0 \%$ to $10 \%$ and alccofine from 0 to $5 \%$. However, increasing the concentration of alccofine 1101 in mixes increased the MDD values than mixes with RHA alone.

\section{REFERENCES}

[1] Arora K. R., Soil Mechanics and Foundation Engineering (Geotechnical Engineering), Standard Publishers Distributors, Delhi, India, 2008.

[2] Basha EA., Hashim R., Mahmud HB., Muntohar AS. (2005). Stabilization of residual soil with Rice Husk Ash and Cement”, Construction and Building Materials.

[3] Kanddulna B., Kisku N., Murari K., Singh JP. (2016). Experimental Study of Clayey Soil with Lime and Rice Husk Ash. International Journal of Engineering Trends and Technology (IJETT).38 (7), 365-372.

[4] Kumar BS., Preethi T.V. (2014). Behavior of Clayey Soil Stabilized with Rice Husk Ash \& Lime. International Journal of Engineering Trends and Technology (IJETT). 11 (1), $44-48$.

[5] Okafor FO., Okonkwo UN. (2009). Effects of Rice Husk Ash on Some Geotechnical Properties of Lateritic Soil. Leonardo Electronic Journal of Practices and Technologies. 15, 6774 .

[6] Rao, D.K., Pranav. P.R.T., and Anusha, M. (2011). Stabilization of Expansive Soil using Rice Husk Ash, Lime and Gypsum- an Experimental Study. International Journal of Engineering Science and Technology. 3(11), 8076-8085.

[7] Shadi VK., Banarase MA. (2015). Experimental Study on Effect of Alccofine on Properties of Concrete-A Review. International Journal of Research in Engineering Science \& Technology. 297-301. 
li $=$

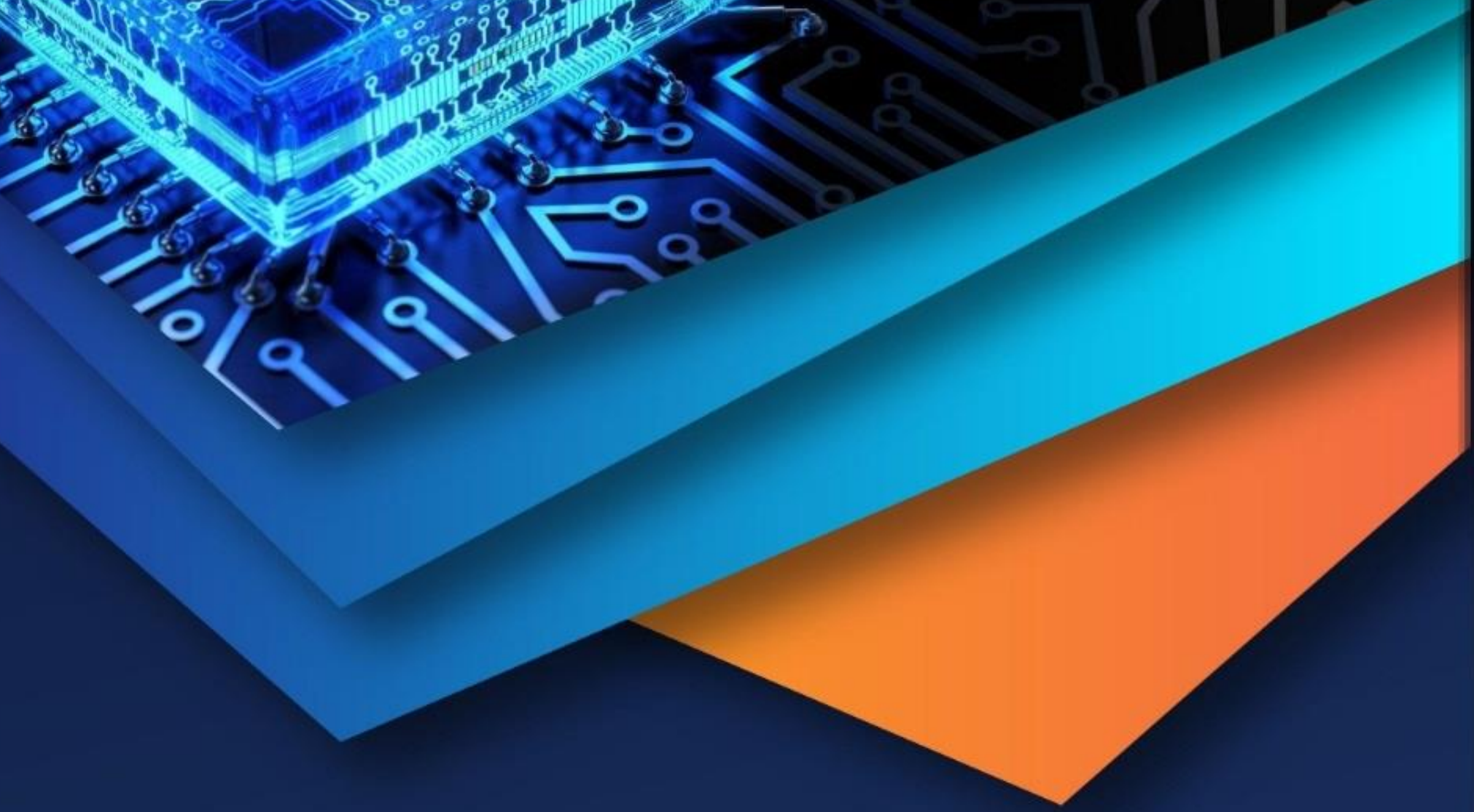

do: cross ref

10.22214/IJRASET

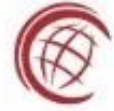

INDEX COPERNICUS

45.98

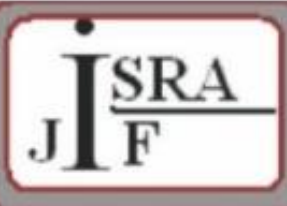

IMPACT FACTOR: 7.129

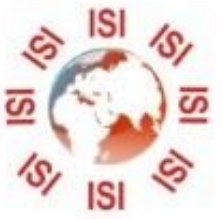

IMPACT FACTOR:

7.429

\section{INTERNATIONAL JOURNAL FOR RESEARCH}

IN APPLIED SCIENCE \& ENGINEERING TECHNOLOGY

Call : $08813907089 @\left(24^{*} 7\right.$ Support on Whatsapp) 